\title{
Career and Technical Education for Sustainability: A Multiple Case Study of Innovative Community College Programs
}

James A. Gregson ${ }^{\mathrm{a}}$, Karen Ruppel ${ }^{\mathrm{b}}$

${ }^{a}$ University of Idaho, ${ }^{\mathrm{b}}$ North Idaho College

This multiple case study explored Career and Technical Education (CTE) programs that were identified as having a focus on sustainability. Using the Association for the Advancement of Sustainability in Higher Education, Sustainability Tracking, Assessment, and Rating System (AASHE STARS) as a conceptual framework, the researchers interpreted whether the social, economic, and environmental concepts of sustainability were included in these programs' curriculum. Findings suggested that several factors impacted program curriculum: (1) attentiveness to industry trends; (2) sustainability as an institutional core value; (3) geographic location of urban versus rural; (4) program maturity; and (5) advisory committee influence. Findings also suggested a unifying definition for sustainability was lacking among these programs though participants demonstrated understanding of some common sustainability concepts.

Keywords: sustainability, green collar workforce development, career and technical education

\section{Introduction}

In recent decades, as the growth of societies and economies has become more interconnected, the collective impact of human living and consumption has assumed global and systemic dimensions. In the last halfcentury, industrialization and globalization have created growth in technology, energy use, resource extraction, and consumerism. Species extinction, declining fisheries, declining food sources, and other forms of human-caused disruption threaten the earth's life cycles (Edwards, 2005; Intergovernmental Panel on Climate Change, 2007 McMichael, 2008). It is apparent these changes pose threats not only to the environment, but also to the economy as well as the health and survival of communities (Hawkin, 2007; McKibben, 2007).

The current ecological crises facing the world, along with the public attention given to sustainability, have advanced as issues of importance in higher education. Many faculty, administrators, policymakers, and employers are focused on efforts to create better educational practices for sustaining the earth's resources. This is evidenced by emerging courses and programs introducing sustainability into curricula; a growth in organizations such as the Center for Ecoliteracy, the Green Schools Alliance, and the Association for the Advancement of Sustainability in Higher Education (AASHE); the retrofitting of campus structures and the building of "green" structures; and the campus implementation of a variety of "green" programs which promote sustainable practices (AASHE, n.d.). Increasingly, educational researchers around the world have explored how education can contribute to the global goal of achieving a sustainable future (Orr, 2003; Rebello, 2003; Sammalisto \& Lindhqvist, 2007; Stephens, Hernandez, Roman, Graham, \& Scholz, 2008; Vare \& Scott, 2007).

Several educational models related to Education for Sustainability (EfS) and greening the curriculum have been identified, such as deploying various courses with a focus on sustainability, reorienting teaching and research in all fields towards sustainability, and raising environmental awareness at colleges and universities through dialogue and involvement in sustainability issues (AASHE, n.d.; Junyent \& Geli de Ciurana, 2008). While conceptual frameworks for EfS exist, little research offers a framework for how to implement EfS in two-year Career-Technical Education (CTE) programs at community colleges (Hyslop, 2009; Negrea, 2008a).

Community colleges, where many CTE programs are located, have been noted as essential to the growing momentum to develop a green workforce (Hyslop, 2009). The rationale for incorporating sustainability concepts in CTE programs is perhaps most greatly reflected in the recent movement toward improving environmental performance in industry (Creech \& Musselwhite, 2008; Payne, 2008; Stone III, 2010; Walmart, 2016), as well as in the growing impetus to implement EfS in higher education in general. As an education sector aimed at producing employees to work in industry, the challenge 
for CTE is to re-orient or design new curricula that instill in students a respect for sustainability concepts and enhance students' competencies to implement sustainability practices in the workplace.

\section{Literature Review}

Career-Technical Education and EfS. In order to situate this research in CTE, it is necessary to understand the role community colleges and CTE play in the higher education system. Since the 1960s, and continuing through the $1990 \mathrm{~s}$, community colleges became more market-oriented in their goals and more businesslike in their behaviors (Dougherty, 1994; Levin, 2002). The role of training for workforce development became more pronounced, and community colleges gained a much more significant economic function (Levin, 2002). CTE plays an important role in community college curricula by aligning program curriculum with major changes in technology while maintaining a focus on local community needs.

A number of studies illustrate the economic advantages for individuals who complete a CTE degree or certificate (Association for Career and Technical Education, 2010; Arenas, 2008; Baum, Little \& Payea, 2011; Grubb \& Lazerson, 2005; National Assessment of Vocational Education, 2004). All of these studies conclude that individuals who complete a CTE degree or certificate earn more than those who take classes without completing a degree. Obviously, the economic advantage of a CTE degree or certificate can remove barriers to higher education and provide opportunity for entry into employment sectors that provide living wages and meaningful work.

Notwithstanding the economic advantages, there are socio-political factors affecting the implementation of EfS into higher education curricula, and in particular into CTE programs (Bowers, 2008a; Calder \& Clugston, 2003; Orr, 2004). CTE has traditionally aligned with business and with major changes in technology. Business and industry practices, efficiency, and profit are foundational to the concepts of CTE programs and in many ways diverge from the concepts of sustainability. Orr (1992) pointed out that one of the difficulties with the idea of sustainable development, one which is also often associated with CTE curriculum (e.g., Gregson, 2010), is that it fails to account for the deeper, complex problems related to the fundamental values underlying modern civilization. According to Orr (1992, 2003), technological sustainability cannot succeed without changes in the values associated with ecological sustainability. This holds equally true for CTE in that the employees of the future must be prepared to handle not only job-specific skills but must also be able to solve complex problems if sustainability is to be achieved.

Green Collar Workforce Development. Sustainability has created two trends in CTE: the development of new programs for green careers and the "greening" of existing programs for jobs that now have some aspect of sustainability infused in them (e.g., hybrid and electric vehicles for automotive technology, "green" building for construction technology) (Gregson, 2010; Jones, 2008; Green Jobs, 2009; Negrea, 2008a). The demand for sustainability education has also created a demand for technical training in areas which support technology aimed at achieving sustainability. Hyslop (2009) claimed a workforce phenomenon is taking place that will require the development of new CTE programs for green industries such as solar panel installers and wind turbine technicians, as well as the need to reorient program curriculum in order to green all other jobs (e.g., agriculture, automotive technology, construction technology). Hyslop (2009) noted that perhaps the most important role of CTE programs is to prepare students to be leaders in the future workforce. By their nature, CTE programs are flexible and dynamic, allowing them to keep up with changing technologies in order to meet the demand for both a skilled and environmentally conscious workforce (Hyslop, 2009).

According to the Environmental Careers Organization (2004), green jobs will be found across all industries and at all levels of education, with the largest number of green jobs being predicted in the nation's energy sector in occupations that require an apprenticeship, professional certificate, or one to two years of postsecondary education. In addition to two-year education degrees and certificates, employers stress that a broad set of green knowledge, which crosses many industries and occupations, will become increasingly important for job advancement (Green Jobs, 2009; Wilhelm, Thomas, Thompson, \& Lee, 2016).

The rationale for incorporating sustainability concepts in CTE programs is also reflected in the growing movement to provide pathways into the middle class for those who are struggling economically (Packer, 2014; Putman, 2015). Examples of recent initiatives and funding that support this movement include The American Recovery and Reinvestment ACT (The White House, 2009) which included over $\$ 500$ million for research and job training projects that prepare workers for green technology jobs, and the United States Department of Labor's Pathways Out of Poverty grants which help workers in disadvantaged communities gain access to green economy jobs (US Department of Labor, 2010). Green jobs have been identified as having the potential to provide quality, family-sustaining jobs that also help to improve our environment (Jones, 2008; Pinderhughes, 2007; Wilhelm et al., 2016).

The need to embrace the critical challenge of EfS in CTE programs is obvious. The emerging transition to a low-carbon and sustainable economy holds promise for job creation. There are new technologies transforming the economic landscape as products, services, and jobs are reoriented toward sustainability (White \& Walsh, 2008). CTE programs already exist which can be updated to 
reflect the growing need for skilled green collar technicians (Gregson, 2010, 2017; Negrea, 2008a). CTE programs are also well positioned to implement sustainability solutions due to their immediate and lasting impact on the workforce. With the demand for environmentally informed technicians growing, community colleges can provide a low-cost, short-term pathway to employment while meeting the needs of the emerging green jobs economy (Negrea, 2008b).

AASHE STARS as a Conceptual Framework for CTE. The literature surrounding EfS in higher education points toward certain crucial themes for implementation such as the use of an integrated, contextualized approach to teaching, as well as consideration of the three pillars of sustainable development: environment, economy, and equity (Burns, 2011; Chase \& Rowland, 2004; Frisk \& Larson, 2011; Gruenewald, 2008; Sipos, Battisti, \& Grimm, 2008). Through its work on sustainable development, the United Nations Educational, Scientific and Cultural Organization (UNESCO, 2005) heightened awareness and recognition of these three "pillars," also known as the "Three Es" of sustainable development, and contributed to them being increasingly used as a conceptual framework.

The complex nature of EfS, along with the need to provide pathways to employment, reinforces the need for a conceptual framework to inform CTE program development. AASHE has developed a standardized campus self-evaluation tool called the Sustainability Tracking, Assessment and Rating System (STARS, 2012) for colleges and universities to measure their sustainability performance. The multiple case study discussed here describes the program development processes used and interprets the connection of the program curriculum to sustainability literacy concepts in the curriculum using the AASHE STARS curriculum criteria as a framework for the interview questions. The AASHE STARS criteria were used because they were created with extensive input from experts in the field of sustainability and were influenced by common sustainability themes cited in the prevailing literature. In order to develop or reorient CTE programs toward more sustainable practices, it is important to consider how (or whether) these themes support the nature of CTE programs.

Applying AASHE STARS to CTE. The following presents the AASHE STARS criteria for curriculum and proposes how it may be suited for CTE program development.

- Courses and or programs educate about how different dimensions of sustainability relate to each other and provide the skills to weave together disparate components of sustainability. CTE programs address not only environmental relationships but are directly linked to local, regional, national, and global economic and social systems. For example, CTE programs directly support food and energy production, manufacturing, and transportation systems all of which affect environmental, social, and economic dimensions of society. Understanding how these systems are interrelated and how they are part of nature's systems is important if we are to achieve sustainability (Gregson, 2017).

- Program degrees and/or courses have identified sustainability learning outcomes. CTE programs are outcomes- and competency-based, allowing instructors to easily adapt program curriculum to include sustainability outcomes. Again, by using the environmental, social, and economic dimensions of sustainability to guide outcomes development, CTE programs can move toward creating sustainability-literate graduates (Gregson, 2010).

- Institutions conduct an assessment of the sustainability literacy of its students. Sustainability literacy goals for students should be assessed in all curricula, including CTE programs. Again, CTE programs are competency and outcomes based making them easy to adapt to sustainability concepts and assess sustainability goals (AASHE STARS, 2012).

- Program degrees and/or courses include sustainability-focused immersive experiences that give students the opportunity to learn in-depth about sustainability challenges and solutions. CTE programs, by their nature, are contextualized within teaching and learning. CTE programs take place in a hands-on learning environment allowing for true immersive experience. Local advisory committees and local industries ensure that the curriculum meets local needs. Many CTE programs provide internships and on-the-job experiences (Ruppel \& Gregson, 2013).

Higher education will likely continue to play a role in achieving EfS at all levels. CTE is part of this role in that its focus is to prepare the nation's workforce. In order to accomplish the literacy themes emerging for sustainability, though, graduates must understand not only green technology skills but also the underlying rationale for sustainability in order to transition to better industry practices. CTE curriculum and instruction focuses on the interrelationship between local, regional, and national systems and touches on most, if not all, of the economic dimensions of sustainability. Its contextual nature aligns well with the need for immersive experiences in sustainability practices that are consistently called for in the literature. The challenge for CTE is not in just integrating green technology into programs, but rather it is how to ensure every CTE graduate actively and responsibly contributes to a just and economically- and environmentally-conscious workforce. It is CTE's responsibility to provide skilled graduates as a foundation for the manufacturing, transportation, agricultural, natural resource, and 
energy/building sectors (Association for Career and Technical Education, 2010). Discovering a flexible framework such as AASHE STARS may be one method for introducing the social, economic, and environmental sustainability literacy concepts into CTE.

\section{Methodology}

This study applies a multiple case study approach. Three community-technical colleges were purposefully selected because of their location in the Pacific and Inland Northwest and for their unique approach to program development specific to their service area and population. Merriam (2002) contended that purposeful sampling is based on the assumption that the researcher wants to ascertain, comprehend, and achieve insight, and, therefore, must select a sample from which the most can be gained.

Purposeful sampling was appropriate for this study based on the presence of both common and unique characteristics. Creswell (2007) suggested multiple sites are selected "to show different perspectives on the same issue" (p. 74). The common criteria used in this study were: (a) that the institution is a comprehensive community college; (b) that the institution had successfully implemented a CTE program focused on sustainability practices; (c) that it had an applied associate of science degree available for the CTE program focused on sustainability practices; (d) that it had non-selective enrollment; and (e) that the institution be located in the Pacific and Inland Northwest. The unique criterion used to select sites were: (a) that the program was an existing program with either reoriented curriculum or new program curriculum; (b) the geographic location of the program; (c) the type or focus of program technical content; and (d) the regional population (urban versus rural).

Identifying and selecting CTE programs oriented toward sustainability would have been difficult in the notso distant past, but the recent emergence of a number of programs in environment-conscious states, such as Oregon and Washington, has resulted in a number of programs that have a focus on sustainability. The Pacific Northwest is considered progressive overall when it comes to sustainability practices. With funding in the past from the Obama administration stimulating program development, the emergence of a strong green economy along the west coast of the U.S., and the popular media's focus on creating green jobs, locating programs in the Pacific Northwest was relatively easy and locating programs in the Inland Northwest challenging but possible. The three cases chosen for this study were: (a) Wind Energy Technology program at College of Southern Idaho located in Twin Falls, Idaho; (b) Energy Management program at Lane Community College located in Eugene, Oregon, and (c) Environmental Technologies and Sustainable Practices program at
Cascadia Community College located in Bothell, Washington.

College of Southern Idaho (CSI), Wind Energy Technology program, Twin Falls, Idaho. The Wind Energy Technician Associate of Applied Science (AAS) degree program at CSI is a relatively new program and may serve as a model for other colleges who endeavor to create the same. The Wind Energy curriculum was designed to prepare students to enter the growing field of wind turbine maintenance and repair. To develop the program, CSI risked entering a relatively unknown and untapped field; thus, creating the program was a learning experience for the college. The curriculum for the Wind Energy program was specific to a skill set that equipped students to work in jobs associated with the maintenance and repair of wind turbines, industrial maintenance, and safety skills. A few of its accomplishments include: the development of a nationally-recognized ladder training device for climbing safety training, a successful wind turbine tower climb with its first cohort of students, and the acquisition of several grants to support unique program equipment needs. Additionally, the development of a solid program curriculum that provides a comprehensive skill set for a technician that will carry over into other renewable energy sectors makes the program both viable and sustainable. CSI is a member of AASHE and at the time of this study was enrolled in the AASHE STARS program (CSI, n.d.).

Lane Community College, Energy Management program, Eugene, Oregon. The Energy Management Associate of Applied Science (AAS) degree program at Lane Community College focuses on energy use patterns for residential and commercial buildings and energy efficiency and alternative energy solutions for high-energy consuming buildings. Lane Community College has been engaged in energy management and environmental initiatives for over two decades. It is a signatory of the American College and University Presidents' Climate Commitment (ACUPCC) and a member of AASHE and has relied upon both internal and external policies and initiatives to guide the quality of its programs and endeavors. It has developed an institutional-wide hierarchy of administrative committee structure, along with subcommittees, that has made sustainability part of the character of the College. Lane's core value of sustainability, along with its recently adopted sustainability policies, ensure nearly all programs and activities have some type of experience or initiative that supports continuous improvement toward sustainability. Recent successes include the addition of 12 sections of courses within the Energy Management program to meet enrollment growth, in addition to new courses added to Energy and to Water Conservation; the receipt of strategic investment funds to help create Energy Management hybrid courses; and the award of the Sustainable Power Quality accreditation credential 
Table 1. Institutional Characteristics of Study Participants

\begin{tabular}{|c|c|c|c|}
\hline Characteristic & $\begin{array}{l}\text { Lane Community College, } \\
\text { Eugene, OR }\end{array}$ & $\begin{array}{l}\text { Cascadia Community } \\
\text { College, Bothell, WA }\end{array}$ & $\begin{array}{l}\text { College of Southern Idaho, } \\
\text { Twin Falls, ID }\end{array}$ \\
\hline Institution Type & Community college & Community college & Community college \\
\hline Program Name & $\begin{array}{l}\text { Energy Management } \\
\text { Technician-AAS Degree }\end{array}$ & $\begin{array}{l}\text { Environmental Technologies } \\
\text { and Sustainability Practices- } \\
\text { AAS Degree }\end{array}$ & $\begin{array}{l}\text { Wind Energy Technician- } \\
\text { AAS Degree }\end{array}$ \\
\hline $\begin{array}{l}\text { Degrees/Certificates } \\
\text { Offered }\end{array}$ & $\begin{array}{l}\text { TC/AAS ( } 1 \text { TC, } 1 \text { degree } \\
\text { option }\end{array}$ & AAS (2 degree options) & C/AAS (3 C options) \\
\hline $\begin{array}{l}\text { New or Reoriented } \\
\text { Curriculum }\end{array}$ & Reoriented & New & New \\
\hline $\begin{array}{l}\text { Institutional Service } \\
\text { Area }\end{array}$ & $\begin{array}{l}\text { Rural/Suburban; Service } \\
\text { district population of over } \\
350,000\end{array}$ & $\begin{array}{l}\text { Urban; combined population } \\
\text { of King and Snohomish } \\
\text { Counties is over 2,644,584 } \\
\text { of which Cascadia partially } \\
\text { serves. }\end{array}$ & $\begin{array}{l}\text { Rural; Service district } \\
\text { population of approximately } \\
180,000 .\end{array}$ \\
\hline Institutional Size & $\begin{array}{l}\text { Approximately } 36,000 \text { credit } \\
\text { and non-credit students }\end{array}$ & $\begin{array}{l}\text { Approximately } 5,000 \text { credit } \\
\text { and non-credit students }\end{array}$ & $\begin{array}{l}\text { Approximately } 10,000 \text { credit } \\
\text { and non-credit students }\end{array}$ \\
\hline $\begin{array}{l}\text { Institutional } \\
\text { Sustainability Core } \\
\text { Value(s) }\end{array}$ & Yes & Yes & Yes \\
\hline $\begin{array}{l}\text { Campus Sustainability } \\
\text { Initiatives }\end{array}$ & $\begin{array}{l}\text { Well-developed initiatives } \\
\text { integrated into operations } \\
\text { and curriculum }\end{array}$ & $\begin{array}{l}\text { Well-developed initiatives } \\
\text { integrated into operations } \\
\text { and curriculum; founding } \\
\text { principle }\end{array}$ & $\begin{array}{l}\text { Emerging initiatives } \\
\text { developed into some } \\
\text { operations; some well- } \\
\text { established programs; some } \\
\text { emerging programs and } \\
\text { courses in the curriculum }\end{array}$ \\
\hline
\end{tabular}

Note: $\mathrm{TC}=$ One year Technical Certificate; $\mathrm{C}=$ Certificate - less than two years; AAS = Associate of Applied Science (two years)

by the Interstate Renewable Energy Council (Lane

Community College, n.d.).

Cascadia Community College, Environmental Technologies and Sustainable Practices program, Bothell, Washington. The Environmental Technologies and Sustainability Practices (ETSP) AAS degree program was designed to prepare students to enter the growing fields of sustainability technology and renewable energy technology. Two curricular tracks allow students to take an educational emphasis in either sustainability technology practices or sustainability business practices (Cascadia Community College, 2011-2012). Its successes include the completion of the design work and models for a community energy retrofit for a high school and an adjacent industrial park for the city of Arlington, Washington; the development of student cohort groups at the beginning of the program to provide a supportive integrated learning environment and increase student retention; and submission of AASHE's STARS, a selfanalysis report, performed and completed by two ETSP program students. In addition to these program-specific successes, the Cascadia administrator is managing five grants which directly support the three CTE programs at Cascadia and the recent relocation of the ETSP program in Cascadia's newly built, LEED-certified Global Arts building which also serves as a systems learning laboratory for the program. Cascadia is a signatory of the
American College and University Presidents' Climate Commitment (ACUPCC) and a member of AASHE. Institutional characteristics and program details are summarized in Table 1 for Cascadia Community College as well as the other two community colleges in the study.

\section{Research Questions}

This study presents a description of program development processes and offers an interpretation of the extent to which sustainability concepts are included in the curriculum. The central research question was "How are three community college CTE programs attending to EfS, and what strategies were used to include EfS in the curriculum?" Three sub-questions that sought to identify sustainability literacy concepts in the curriculum are addressed in this paper:

1. To what extent have the CTE programs used STARS to both define and guide curricular decisions for sustainability?

2. To what extent have the CTE programs addressed social and economic as well as environmental challenges as reflected by STARS? 3. What, if any, immersive experiences, as referenced by STARS, are incorporated into these CTE programs that allow for in-depth learning and 
practice of sustainability challenges and solutions related to students' programs of study?

\section{Data Collection}

The key data-gathering strategies used were interviews, focus groups, and document analysis. The interviews took place with administrators, faculty, and advisory committee members affiliated with the identified CTE programs and took place at the respective community college. The primary interview questions were designed to elicit broad responses centered on program design and development. Secondary interviews with faculty and focus groups with students were designed to elicit in-depth information to be interpreted for sustainability literacy concepts. In addition to the interviews, document analysis supported the information provided in the responses to the primary interview questions. Documents included program curriculum, textbooks, supplemental materials, assignments, assessments, course syllabi, and budgets.

These results are organized around the interpretive data, which sought to identify how sustainability literacy concepts are included in the program curriculum at the three institutions under study. The program instructor interviews were held with the lead instructor for each CTE program. The program advisory committee member interviews were held with one advisory committee member for each CTE program, and these participants were identified by the program instructor. The program instructor and program advisory committee member interview guides included questions designed to provide both descriptive data about program development and interpretive data seeking sustainability literacy concepts. The interpretive data was derived from questions seeking the advisory committee members' and the program instructors' understanding of sustainability literacy concepts in the context of AASHE STARS. The student focus groups included volunteers from each program, the majority of whom were enrolled in the second year of their respective programs. The student focus group interview questions were designed to elicit students' understanding of sustainability concepts in the context of AASHE STARS. This research was approved by the University of Idaho Internal Review Board.

\section{Findings}

Institutional Variance. The community colleges in this study reported being constrained by external and internal mandates regarding accountability and the development of CTE programs, though developing a renewable energy program or an energy management and conservation program is an uncertainty for any college in an emerging market and in a rapidly changing industry. It is notable that sustainability was a factor considered by both Lane and Cascadia, but was not a factor considered by CSI when developing their programs. CSI administrators and faculty were clear that although sustainability is important to the college, the wind energy program was a workforce-driven initiative.

To summarize the program development processes, data supporting the processes identified by the three colleges showed that although each institution has governing policies and structures, as CTE programs they must follow the Federal guidelines put forth in the Perkins Act (United States Department of Education, 2006). Therefore, the CTE program development requirements in each college are more alike than different. The data also showed factors that may have contributed to differing characteristics in these three programs. Those factors are: (1) attentiveness to industry trends; (2) sustainability as an institutional core value; (3) geographic location of urban versus rural, progressive versus conservative, (4) program maturity; and (5) advisory committee influence.

Research Question 1: To what extent have the CTE programs used STARS to both define and guide curricular decisions for sustainability? The first curriculum criterion identified in AASHE STARS gives credit to an institution when a definition of sustainability has been identified and articulated. A definition for sustainability was sought from the program instructors, the program students, and the program advisory committee members. Although themes that support an integrated curriculum focused on sustainability are evident in the EfS literature, they are not evident in the literature for CTE. According to the three program instructors, the focus of their programs is to prepare students for employment. To accomplish this, a definition for sustainability was not a condition for the program curriculum.

Field notes associated with this phase of the focus groups indicated the students struggled with their definition of sustainability and often parroted one another or went along with a group response; only a few students provided original thoughts on a definition. The findings for the students' definition of sustainability reflected that, for the most part, the students viewed sustainability as preservation or renewal of resources.

The findings did suggest that when students learn to take action supporting sustainability concepts through their CTE curriculum, they create a contextual definition for sustainability through those actions. Perhaps what is most important is that a definition of sustainability may be implicit in the curriculum. This idea was reflected in several instructor comments, such as, “...we started focusing in on sustainability in the built environment... Our students know that if they can have an effect...by producing either new construction or retrofitting, they know they are contributing to sustainability" (Lane Instructor, personal communication, April 27, 2011). In other words, the instructors believed that by encoding a desire for change 
through action, it becomes easier for other things to change, and a definition evolves through action rather than words.

In summary, the findings for the first research question supported that a single definition for sustainability does not exist within the participants' responses. Notable among all of the responses was an indication of the need to balance our use of resources. Perhaps most telling in these findings, as illustrated in the differing and conflicting definitions for sustainability, is the indication of an absence of a language for sustainability.

Research Question 2: To what extent have the CTE programs addressed social and economic as well as environmental challenges as reflected by STARS? The second criterion identified by AASHE STARS states the social, environmental, and economic concepts of sustainability should be considered in all aspects of the curriculum. In fact, according to AASHE (2012), the concept of sustainability shaped the development of STARS and is fundamental to the rating system. AASHE (n.d.) cited the definition for sustainability put forth in Our Common Future, better known as the Brundtland Report (UNWCED, 1987, p. 1) as a reference for STARS, reinforcing the widely accepted definition of "meeting the needs of the present without compromising the ability of future generations to meet their own needs." AASHE (2012) further explained that STARS attempts to translate a broad and inclusive view of sustainability to measurable objectives at the campus level, and that all of its credits are related to an institution's environmental, social, and economic performance.

As addressed in the literature review, the extensive discussion surrounding sustainability has produced a variety of definitions with a growing recognition for the economic, environmental, and social aspects of sustainability. The combined responses of the students and the instructors documented varying knowledge of the three concepts of sustainability. The analysis of the instructor responses revealed three different perspectives ranging from a purely business and employability perspective, to a highly integrated point of view focused on an implicit definition of sustainability made clear through student actions. The students' responses mostly reflected the beliefs of their instructors and lacked sophisticated understanding of the interrelationship between the three concepts of sustainability. In some instances student responses reflected concern for how they live now and about how their children will live into the future. Some students reflected thoughtfully on the poor and needy and on the fact that choices are not always available for those most in need. The majority of student responses were more focused on societal challenges and politics reflecting local energy and conservation issues in relation to their program of study. Lastly, most students also discussed the changing technology in their field of study and were excited about and focused on the potential emerging jobs that may be available in their future. Table 2 provides student responses that in some instances

Table 2. Student Perspectives on the Interrelatedness of the Three Concepts of Sustainability

\begin{tabular}{|c|c|c|}
\hline & Interrelatedness & \\
\hline College & Key Terms & Characteristic Responses \\
\hline $\begin{array}{l}\text { CSI } \\
\text { Students }\end{array}$ & None & None \\
\hline $\begin{array}{l}\text { Cascadia } \\
\text { Students }\end{array}$ & $\begin{array}{l}\text { Interconnected } \\
\text { Multi-tiered } \\
\text { Putting them altogether }\end{array}$ & $\begin{array}{l}\text { - They are definitely interconnected...I think that the social aspect is actually } \\
\text { going to be the hardest one to deal with. Getting people to understand that } \\
\text { and then realize that things are going to be taken away...then of course the } \\
\text { environmental part will be better...As more and more people understand } \\
\text { that this is what we are going to have to do then hopefully we will see the } \\
\text { economic boom. } \\
\text { - It is a multi-tiered approach in order to really get it to where we need to be. } \\
\text { - I think that putting them altogether is still a lot better than what we are } \\
\text { doing now. }\end{array}$ \\
\hline $\begin{array}{l}\text { Lane } \\
\text { Students }\end{array}$ & Triple Bottom Line & $\begin{array}{l}\text { - We had a sustainability class where we talked about the triple bottom line } \\
\text { and how everything affects everything ... we can't grow a society without } \\
\text { considering the resources required, and you can't take more from the earth } \\
\text { than it has the capability of reproducing without detrimental consequences } \\
\text { to all of those three factors. } \\
\text { - I think that we have to expand on what was said...the society here that we } \\
\text { are familiar with is kind of counterproductive as far as sustainability goes } \\
\text { and the economic impact is; if we are economically disadvantaged then it's } \\
\text { more difficult for us to make our purchasing power sustainable. Also } \\
\text { environmentally, I just think that we don't have to look very far into our } \\
\text { living habits to realize the damage we are doing to our environment both } \\
\text { here and abroad. }\end{array}$ \\
\hline
\end{tabular}


reflect understanding when asked about the interrelationship of the concepts of sustainability.

Research Question 3: What, if any, immersive experiences, as referenced by STARS, are incorporated into these CTE programs that allow for in-depth learning and practice of sustainability challenges and solutions related to students' programs of study? The final AASHE STARS criterion used in this study gives credit to an institution for providing immersive experiences that allow students to witness and learn in-depth about sustainability challenges and solutions. To earn credit, a program must either concentrate on sustainability, including its social, economic, and environmental dimensions, or examine an issue or topic using sustainability as a lens (AASHE STARS, 2012). It is the nature of CTE programs to provide immersive experiences through laboratory coursework, or external group projects, or internships, or a combination of any of these experiences. In fact, two of the key principles for CTE needed to succeed in the future workforce identified by Secretary's Commission on Achieving Necessary Skills (SCANS, 2000) include to learn abstract concepts through practical activities, and to connect school to work (Baker, Hope \& Karandjeff, 2009). These two principles are the foundation of CTE programs, thus, the contextualized approach to learning common to CTE may create a learning environment that would allow for in-depth learning and practice of sustainability challenges and solutions.

The findings for this research question show all three programs provide immersive experiences for students. For the most part, the experiences are provided through internship and campus laboratory settings. However, the two energy management programs are developing integrated group projects in their respective communities as learning experiences. The instructor and administrator for the alternative energy program, working against technical and safety challenges, have also created a comprehensive and impressive simulated learning experience for their students. The findings for this question show all three programs provide immersive experiences for the students that allow for in-depth learning and practice of sustainability concepts. Although the instructors responded that learning sustainability concepts are not explicit in the curriculum, and that they do not assess for sustainability literacy, the students' responses regarding their immersive experiences do reflect that learning sustainability may be implicit in the curriculum.

\section{Conclusions and Significance of the Research}

The cases in this study provide a rich, descriptive representation of three innovative CTE energy management/alternative energy programs at the community college level. Lane Community College,
Cascadia Community College, and College of Southern Idaho are leaders for providing innovative CTE programs in emerging industries. By identifying the processes, the challenges, and the opportunities experienced by these colleges during the development of their respective CTE programs, other community colleges can benefit from these insights when they seek to develop similar programs. Whether the intent of these three programs was to include EfS in the curriculum, it is worth considering whether EfS may no longer be considered an option but rather an obligation for $\mathrm{CTE}$ and for all of higher education.

The results of this study suggest that CTE praxis may be an excellent model for how to implement sustainability into the curriculum and how to teach students to take action. The results of this study also showed that a specific framework for EfS may not be necessary or even possible. AASHE STARS was created using the common themes for sustainability literacy evident in the literature but intentionally does not prescribe a specific framework; the flexibility of the STARS model fits with the constantly developing and contextual nature of CTE programs.

Although the literature revealed progress has been made toward making EfS more important to the strategic goals and initiatives for colleges and universities, progress toward pedagogical changes in higher education are only emerging (Calder \& Clugston, 2003; Jickling, 2003; Leal Filho, et al., 2008; Orr, 2004; Orr, 2010; Orr, 2011; Peters, 2008; Sterling, 2004). This may be partly due to the absence of an agreed-upon framework for introducing EfS into curricula (Gerbilsky et al., 2005), or into CTE curriculum, which was the focus of this study. AASHE STARS was presented as a potential framework for introducing sustainability concepts into CTE program curricula. Research is needed to better understand the best practices for implementing EfS into all levels of education and the impact of these practices on the overall effect of sustainability on society.

\section{References}

American College and University Presidents' Climate Commitment (n.d.). Commitment text. Retrieved from http://www.presidentsclimatecommitment.org/

Arenas, A. (2008). Connecting hand, mind, and community: Vocational education for social and environmental renewal. Teachers College Record, 110 (2), 377-404.

Association for the Advancement of Sustainability in Higher Education (AASHE, 2012). Sustainability tracking, assessment and rating system, STARS version 1.2 technical manual, February 2012. Retrieved from http://www.aashe.org/files/ documents/STARS/stars_1.2_technical_manual.pdf 
Association for the Advancement of Sustainability in Higher Education (AASHE, n.d.). About AASHE. Retrieved from http://www.aashe.org/about

Association for Career and Technical Education. (2010). CTE: Education for a strong economy. Retrieved from http://www.acteonline.org/uploadedFiles/ About_CTE/files/CTE_Strong_Economy_FactShee t.pdf

Baker, E. D., Hope, L. \& Karandjeff, K. (2009). Contextualized teaching \& learning: A faculty primer. A Review of Literature and Faculty Practices with Implications for California Community College Practitioners, Center for Student Success/RP Group, Academic Senate for California Community Colleges Basic Skills Initiative, and the Bay Area Workforce Funding Collaborative, 1-72. Retrieved from http://www.cccbsi.org/Websites/basicskills/Images/ CTL.pdf

Baum, S., Little, K., \& Payea, K. (2011). Trends in community college education: Enrollment, prices, student aid, and debt levels. Trends in Higher Education Series, College Board Advocacy \& Policy Center, 3-31. Retrieved from http://advocacy.collegeboard.org/sites/default/files/ 11b_3741_CC_Trends_Brief_WEB_110620.pdf

Bowers, C. A. (2008). University reform in an era of global warming. Eugene, Oregon: Eco-justice Press.

Burns, H. (2011). Teaching for transformation: (Re)designing sustainability courses based an ecological principles. Journal of Sustainability Education, 2.

Calder, W. \& Clugston, M. (2003). Progress toward sustainability in higher education. Environmental Law Reporter, News \& Analysis, 33, 10003-10021.

Cascadia Community College (2011-2012). Cascadia community college catalog 2011-2012. Retrieved from http://www.cascadia.edu/Files/Catalog2011_12.pdf

Chase, G., \& Rowland, P. (2004). The Ponderosa Project: Infusing sustainability in the curriculum. In P. F. Barlett \& G. W. Chase, G. (Eds.). Sustainability on campus: Stories and strategies for change (pp. 91-106). Cambridge, MA: MIT Press.

College of Southern Idaho (2011-2012). CSI catalog. Retrieved from http://www.csi.edu/catalog/

Creech, D. \& Musselwhite, N. (2008). Building for the next billion. Economic Development Journal, 1522

Creswell, J. (2007). Qualitative inquiry and research design: Choosing among five approaches (2nd ed.). Thousand Oaks, CA: Sage.

Dougherty, K. J. (1994) Contradictory college: The conflicting origins, impacts, and futures of the community college. Albany, NY: State University of New York Press.
Edwards, A. R. (2005). The sustainability revolution: Portrait of a paradigm shift. Gabriola Island, BC: New Society Publishers.

Edwards, A. R. (2010). Thriving beyond sustainability: Pathways to a resilient society. Gabriola Island, BC: New Society Publishers.

Environmental Careers Organization (2004). The eco guide to careers that make a difference: Environmental work for a sustainable world. Washington DC: Island Press.

Frisk, E. \& Larson, K. L. (2011). Educating for sustainability: Competencies and practices for transformative action. Journal of Sustainability Education, 2.

Gerbilsky, L., Rost, J., Demianenko, V., KnappMeimberg, M., Küster, D., Maile, S.,\& Svirskis, A. (2005). An integrated conceptual framework for education for sustainability. Proceedings of the 1st European Networks Conference on Sustainability in Practice: 263-268. Berlin.

Green jobs and their role in our economic recovery. Hearing before the Subcommittee on Workforce Protections, of the Committee on House, Education, and Labor, $111^{\text {th }}$ Cong. (2009) (testimony of Kathy Krepcio). Retrieved from http://edlabor.house.gov/documents/111/pdf/testim ony/20090331KathyKrepcioTestimony.pdf

Gregson, J.A. (2017, May). Critical vocationaltechnical education and training: Learning for economy, environment, and equity. A presentation for the 3rd International Conference on TVET in the Caribbean. Montego Bay, Jamaica.

Gregson, J. A. (2010). A conceptual framework for green career and technical education: Sustainability and the development of a green-collar workforce. Journal of Technical Education and Training, 2(1), 113-126.

Grubb, W. N. \& Lazerson, M. (2005). Vocationalism in higher education: The triumph of the education gospel. The Journal of Higher Education, 76(1), 325.

Gruenewald, D. A. (2008). The best of both worlds: A critical pedagogy of place. Educational Researcher, 32(4), 3-12.

Hawkin, P. (2007). Blessed unrest: How the largest social movement in history is restoring grace, justice, and beauty to the world. New York, NY: Penguin Books LTD.

Hyslop, A. (2009). CTE's role in energy and environmental sustainability. Techniques, 22-24.

Intergovernmental Panel on Climate Change. (2007). WGI fourth assessment report, climate change: The physical science basis, summary for policymakers. Retrieved from https://www.ipcc.ch/publications and_data/publications_ipcc_fourth_assessment_rep ort_synthesis_report.htm 
Jickling, B. (2003). Environmental education and environmental advocacy: Revisited. Journal of Environmental Education, 34(2), 20-27.

Jones, V. (2008). The green collar economy: How one solution can fix our two biggest problems. New York, NY: Harper Collins.

Junyent, M. \& Geli de Ciurana, A. (2008). Education for sustainability in university studies: A model for reorienting the curriculum. British Educational Research Journal, 34, 763-782. doi: 10.1080/01411920802041343

Lane Community College (n.d.). Website. Retrieved from www.lanecc.edu

Leal Filho, W., Manolas, E. \& Pace, P. (2008). Education for sustainable development: Current discourses and practices and their relevance to technology education. International Journal of Technology and Design Education, 19, 149-165. doi: 10.1007/s10798-008-9079-z

Levin, J. S. (2002). Globalizing the community college: Strategies for change in the twenty-first century. New York, NY: Palgrave Macmillan.

McKibben, B. (2007). Deep economy: The wealth of communities and the durable future. New York, NY: Henry Holt and Company, LLC.

McMichael, A. J. (2008). Population, human resources, health, and the environment: Getting the balance right. Environment, 50 (1), 46-59.

Merriam, S. B. \& Associates (2002). Qualitative research in practice: Examples for discussion and analysis. San Francisco, CA: Jossey-Bass.

National Assessment of Vocational Education (2004). Final report to Congress, 2004. Retrieved from http://www2.ed.gov/rschstat/eval/sectech/nave/nave final.pdf

Negrea, S. (2008a). Green collar jobs: The next industrial revolution. Community College Trustee Quarterly, 12-13.

Negrea, S. (2008b). The case for going green. Community College Trustee Quarterly, 30-31.

Orr, D. W. (1992). Ecological literacy: Education and transition to a postmodern world. Albany, NY: State University of New York.

Orr, D. W. (2003). Viewpoint: Planning to learn. Planning for Higher Education, 31(3), 77-81.

Orr, D. W. (2004). Earth in mind: On education, environment, and the human prospect. Washington D.C.: Island Press.

Orr, D. W. (2010). What is higher education for now? State of the World 2010, 75-82. Worldwatch Institute, New York, NY: W. W. Norton.

Orr, D. (2011). Hope is an imperative: The essential David Orr. Washington D.C.: Island Press.

Packer, G. (2014). The unwinding: An inner history of the new America. New York, NY: Macmillan.

Payne, J. E. (2008). On the dynamics of energy consumption and output in the US. Applied Energy, 86, 575 -577. doi: 10.1016/j.apenergy.2008.07.003
Peters, J. (2008, November/December). Destined for failure. Orion Magazine. Retrieved from: http://www.orionmagazine.org/index.php/articles/ar ticle/3648/

Pinderhughes, R. (2007). Green collar jobs: An analysis of the capacity of green businesses to provide high quality jobs for men and women with barriers to employment. A case study of Berkeley, California. Funded by the City of Berkeley Office of Energy and Sustainable Development.

Putnam, R.D. (2015). Our kids: The American dream in crisis. New York, NY. Simon and Schuster.

Rebello, D. (2003). What is the role for higher education institutions in the United Nations Decade of Education for Sustainable Development? Paper presented at the International Conference on Education for a Sustainable Future, Prague, Czech Republic. Retrieved from http://www.iau-aiu.net/ content/pdf/Rebello.pdf

Ruppel, K.R. \& Gregson, J.A. (2013, April). Education for Sustainability in Career and Technical Education: A Multiple Case Study of Innovative Community College Programs. A presentation for the American Education Research Association. San Francisco, CA.

Sammalisto, K. \& Lindhqvist, T. (2007). Integration of sustainability in higher education: A study with international perspectives. Innovative Higher Education, 32, 221-233. doi: 10.1007/s10755-0079052-x.

Secretary's Commission on Achieving Necessary Skills (2000). What work requires of schools. A SCANS report for America 2000. Washington, D.C.:

SCANS, U.S. Department of Labor. Retrieved from http://wdr.doleta.gov/SCANS/whatwork/whatwork. pdf

Sipos, Y., Battisti, B. \& Grimm, K. (2008). Achieving transformational sustainability learning: Head, hands and heart. International Journal of Sustainability in Higher Education, 9(1), 68-86. doi: 10.1108/14676370810842193

Stephens, J. C., Hernandez, M. E., Roman, M., Graham, A. C. \& Scholz, R. W. (2008). Higher education as a change agent for sustainability in different cultures and contexts. International Journal of Sustainability in Higher Education, 9(3), 317-338. doi: $10.1108 / 14676370810885916$

Sterling, S. (2004). Higher education, sustainability, and the role of systematic learning. In Corcoran, P. B. and Wals, A. E. J. (Eds), Higher education and the challenge of sustainability: Problematics, promise, and practice (pp. 49-70). The Netherlands: Kluwer.

Stone, J. R., III (2010). It isn't easy being green, or is it? Techniques, 42-45.

United Nations Educational, Scientific, and Cultural Organization (2005). Framework for an international implementation scheme. Retrieved 
from http://unesdoc.unesco.org/images/0014/ 001486/148654e.pdf

United Nations World Commission on Environment and Development (1987). Our common future. Retrieved from http://www.un-documents.net/ wced-ocf.htm

United States Department of Education (2006). Carl D. Perkins career and technical education act of 2006. Retrieved from http://www2.ed.gov/policy/sectech/ leg/perkins/index.html

United States Department of Labor (2010). U.S. Department of Labor announces $\$ 150$ million in 'Pathways Out of Poverty' training grants for green jobs. [Press Release]. Retrieved from http://www.dol.gov/opa/media/press/eta/eta201000 39.htm

Vare, P. \& Scott, W. (2007). Learning for change: Exploring the relationship between education and sustainable development. Journal of Education for
Sustainable Development, 1(2), 191-198. doi: 10.1177/097340820700100209

Walmart (2016). Walmart 2016 global responsibility report. Retrieved from http://corporate.walmart.com/2016grr/using-ourstrengths-to-help-others

White House, Task Force on the Middle Class (2009). Green jobs: A pathway to a strong middle class. [Staff Report]. Retrieved from http:// www.whitehouse.gov/assets/documents/mctf_one staff_report_final.pdf

White, S., \& Walsh, J. (2008). Greener pathways: Jobs and workforce development in the clean energy economy (Workforce Alliance Research Report). Retrieved from http://www.cows.org/pdf/rpgreenerpathways.pdf

Wilhelm, K., Thomas, A., Thompson, K., \& Lee, R. (2016). Sustainability jobs: The complete guide to landing your dream green job. Seattle, WA: Seattle Business Consulting. 